ks. Wojciech Rzeszowski Prymasowskie Wyższe Seminarium Duchowne w Gnieźnie

\title{
Formacja ludzka w przygotowaniu do kapłaństwa
}

\section{HUMAN FORMATION IN PREPARATION FOR THE PRIESTHOOD}

Priestly vocation is a great gift placed in a fragile vessel of a human heart ( 2 Cor. 4,7 ). This raises gratitude to God but also the need to care for yourself, especially for intensive human formation, since it is difficult to be a mature priest without being a mature human.

Taking advantage of anthropological study a spiritual seminary should initiate in its seminarians such a dynamics of development which will last a lifetime. The idea is to live maturely, consciously and deeply so the priesthood was the way to realize God's vocation, not a way to search yourself.

The concern to attain such maturity will demand getting to know yourself, the capability to build relationships, achieving a balance in the emotional realm, ability to make responsible choices, healthy conscience and pastoral love. In the end the point is to shape your humanity on the model of Christ the Good Shepherd.

Everybody is personally responsible for their development but nobody is alone on this way. We receive a vocation in Church and for Church therefore by seminary tutors it accompanies us in the process of discernment and realization of vocation. They will fulfill their mission only when they are people of mature and consistent personality because the tutor himself is always the most creative tool of upbringing. They should also show a good understanding of a human person on their emotional, intellectual and spiritual level since then they will understand and support seminary students and make appropriate decisions concerning their future. 
Key words: preparation for the priesthood, human formation, human maturity and realization of vocation, spiritual seminary.

\section{Gliniane naczynia}

Powołanie kapłańskie jest wielkim darem, który został złożony w "glinianych naczyniach" kruchej ludzkiej natury (por. 2 Kor 4,7). $\mathrm{Z}$ jednej strony rodzi to zachwyt nad tajemnicą powołania i wdzięczność za hojność Stwórcy, z drugiej jednak obawę o przyszłość. Kiedy uświadomimy sobie w jak nowym, wielokulturowym i duchowo zagubionym świecie dziś żyjemy, budzi się pełne niepokoju pytanie, co zrobić, by nie utracić tak cennego daru? Jak ochronić kruche naczynie ludzkiego serca, by nie uległo zniszczeniu lub nie zostało uwiedzione przez pozorny urok „kultury chwili” (Benedykt XVI)?

\section{Łaska buduje na naturze}

Choć sercem formacji do kapłaństwa jest życie duchowe, to jednak jej fundamentem pozostaje zawsze formacja ludzka. Bez dojrzałego człowieczeństwa trudno mówić o dojrzałym kapłaństwie. Aby posługa duszpasterska

była po ludzku jak najbardziej wiarygodna i łatwa do przyjęcia, kapłan winien kształtować swoją ludzką osobowość w taki sposób, by stawać się dla innych pomostem, a nie przeszkodą w ich spotkaniu z Jezusem Chrystusem Odkupicielem człowieka (PDV 43)1.

Troska o osiągnięcie dojrzałości ludzkiej jest tak ważna, gdyż bez niej , cała formacja kapłańska byłaby pozbawiona swego niezbędnego fundamentu" (PDV 43). To też sprawia, że jej cele są liczne: poznanie i zrozumienie siebie, umiejętność budowania relacji międzyosobowych i współpracy z innymi, osiągnięcie równowagi w sferze zmysłowo-uczuciowej, zdolność dokonywania odpowiedzialnych i trwałych wyborów, ukształtowane sumienie, pasterska miłość, prawość, uczciwość i wiele innych Ostatecznie chodzi o to, by ukształtować swoje człowieczeństwo na wzór samego Chrystusa - Dobrego Pasterza. W praktyce realizacja powyższych celów nie zawsze się udaje. Człowiek bowiem, pod wpływem nieuporządkowanych uczuć, wewnętrznych ograniczeń i niespójności oraz różnych egzystencjalnych okoliczności może dojrzałości tej

Adhortacja apostolska Jana Pawła II Pastores dabo vobis o formacji kapłanów we współczesnym świecie, Rzym 1992. 
nie osiągnąć. Jej brak rodzi trudności w kapłańskim życiu oraz może zagrażać jego trwałości. Osoba niedojrzała zdolna jest do tak głębokiej subiektywizacji i reinterpretacji przeżywanych doświadczeń, że może Antropologia teologiczna zaprzeczyć nawet temu, co jeszcze niedawno było dla niej oczywiste, niepodważalne i święte. $Z$ pokorą trzeba uznać, jak mówi to watykański dokument o przygotowaniu do życia w celibacie, że historia kapłanów, którzy zawiedli, jest zazwyczaj historią ludzi, którzy zawiedli (por. Wskazania 25)2.

Warto pamiętać, że najbardziej wymagającym i surowym egzaminatorem nie będzie tu seminaryjny profesor, ale życie. Właśnie proza codziennego życia brutalnie weryfikuje naszą ludzką kondycję. Konsekwencje takiego stanu rzeczy bywają dramatyczne i bolesne, zarówno dla kapłanów, jak i wiernych. Paul Marx napisał kiedyś, że „Bóg wybacza zawsze, człowiek czasami, a natura nigdy”. I choć myśl ta nosi w sobie pewne uproszczenie, to jednak zlekceważenie jej może mieć katastrofalne skutki.

Przeżywanie kapłaństwa w wymiarze osobistym - jako wewnętrznej tożsamości oraz wspólnotowym - jako posługi względem braci i Kościoła, wymaga predyspozycji duchowych, intelektualnych i moralnych oraz zrównoważonej i spójnej osobowości. Im większa jest dojrzałość osobowa kandydatów do kapłaństwa (choć nie można tu stosować tylko zasady proporcjonalności), tym pełniejsza współpraca z łaską. Nie kwestionujemy tu działania łaski, która może dokonywać rzeczy wielkich, nawet w tym, kto jest niewielki, ale próbujemy zachować życiowy realizm i unikać pułapki zbyt optymistycznego, życzeniowego myślenia, gdyż jest ono niebezpieczne.

\section{Poznawanie i kształtowanie siebie}

Nawet najlepsze Seminarium Duchowne nie jest w stanie przygotować kandydatów do kapłaństwa w sposób idealny. Jednak każde powinno zainicjować $\mathrm{w}$ alumnach taką dynamikę rozwoju wewnętrznego, która będzie trwać i dojrzewać przez całe życie, umożliwiając tzw. formację permanentną. U podstaw tego procesu leży odkrycie prawdy o sobie - poznanie własnej kruchości oraz doświadczenie miłości Boga, która pomimo, a może bardziej, pośród tej słabości, pragnie objawiać swoją moc. Poznanie siebie, to wejście w świat różnorodnych uwarunkowań psychicznych, fizycznych, duchowych.

Kongregacja ds. Wychowania Katolickiego, Wskazania wychowawcze dla formacji do celibatu kapłańskiego. Rzym 1974. 
Nie jest to zadanie łatwe, bo jak zapewnia prorok Jeremiasz: „Serce jest zdradliwsze niż wszystko inne i niepoprawne - któż zdoła je zgłębić?" (Jr 17, 9). Osoby w wieku około 20 lat, typowym dla wstępowania do Seminarium Duchownego w Polsce, zazwyczaj wiele przeżywają, ale niewiele reflektują i mało rozróżnią. Na początku formacji jest zazwyczaj wiele młodzieńczego optymizmu, a mało zdrowego krytycyzmu. Dopiero dłuższa droga życia, osobiste wzloty i upadki, a także udział w życiu innych, urealniają myślenie o sobie i otaczającym świecie. Kandydaci do służby Bożej, choć pociągani przez sprawy duchowe, osobami duchowymi najczęściej jeszcze nie są. Noszą w sobie wiele dobrych pragnień i szlachetnych ideałów, chęć oddania Bogu i służenia innym, ale też mało znają siebie i nie mają doświadczenia życiowego. Mają w sobie cenny potencjał, który jednak musi w nich dojrzewać, by wydać właściwy owoc.

By praca nad sobą nie była grą pozorów lub budowaniem „zamków na piasku”, bo to w przyszłości grozi „katastrofą budowlaną”, domaga się głębszego wejścia w siebie i poznania swoich potrzeb psychicznych oraz stylu ich realizacji. Niektóre z nich są zauważalne, ale większość jest ukrytych i choć zawsze jakoś manifestują swoją obecność przez nasze postawy, my nie zawsze je dostrzegamy. W każdym człowieku istnieje współzależność pomiędzy tym, co świadomie wybieram a nieświadomymi potrzebami psychicznymi. Tak też jest $\mathrm{z}$ wyborem stanu kapłańskiego czy życia zakonnego, gdyż motywacja powołaniowa jest zazwyczaj wielowarstwowa.

Jeśli wybieramy wartości, które korespondują z naszymi potrzebami i są z nimi zgodne, to mówimy wówczas o spójności wewnętrznej, która sprawia, że człowiek jest zintegrowany. To, co mówi jest jednoznaczne, a jego działanie zgodne z przekonaniami, twórcze i skuteczne. Gdy natomiast brak tej zgodności, a często tak bywa, wówczas niespójność psychiczna rodzi wewnętrzne konflikty, prowadzi do rozdarcia i utrudnia realizację zakładanych celów. Człowiek popychany jest wówczas ku różnym wyborom nie tyle przez wartości, co raczej przez wtórne korzyści. Jeśli tak się dzieje, to niespójny psychicznie ksiądz czy kleryk, pod szyldem szlachetnych działań, zazwyczaj szuka realizacji siebie. Może on wówczas podejmować w Kościele różne dzieła, wyglądające nawet pobożnie, ale wewnętrznie będzie napędzany inną dynamiką - potrzebą zrealizowania ukrytych potrzeb. Może np. bardzo starannie przygotowywać się do kazań i mieć opinię gorliwego kaznodziei, ale warto zapytać, z jakiego powodu on to czyni? Czy płynie to z dynamiki życia słowem Bożym i miłości pasterskiej - troski o zbawienie dusz? A może są w tym ukryte jeszcze inne cele, np. potrzeba 
dowartościowania siebie, potrzeba ekshibicjonizmu i afirmacji, bycia podziwianym, skupiania na sobie uwagi?

Osoby niespójne w dużej mierze napędzane są ukrytym wewnętrzAntropologia teologiczna nym przymusem, a nie miłością i troską o innych. Trudno im więc działać z czystą intencją. Stąd przy realizacji kolejnych zadań będzie rodzić się dodatkowe napięcie, większa utrata energii, szybsze zmęczenie, a w przypadku porażki mocne reakcje emocjonalne - uczucie zawodu, gniew, rozżalenie czy gorycz. Przyglądanie się tym reakcjom, zwłaszcza negatywnym, może nas wiele nauczyć. Nierozpoznane i nieprzepracowane niespójności mogą sprawić, że nawet w duszpasterstwie, zamiast służyć innym, często się ich używa do realizacji nieświadomych potrzeb.

Osoba niespójna psychicznie nie jest osobą chorą czy zaburzoną, bo nie o patologię tu chodzi, ale o doświadczenie dotykające większości ludzi. Nie mówimy tu również o złej woli, lenistwie lub lekceważeniu świata wartości. Osoba niespójna, jakby niechcący oddala się od wartości i nie potrafi ich trwale asymilować. Chce otworzyć się na Boga i jest do tego zdolna, jednak nie jest w stanie tego uczynić. Dlatego często przeżywa te same trudności i uczucie niemocy w realizowaniu odległych celów. To rodzi następnie powracające poczucie porażki, bezsilności i niestałości. Problemy te przynoszą zniechęcenie i frustrację, a z czasem prowadzą do wygodnego przystosowania (konformizmu) albo do cynicznego odrzucenia ideałów, które wcześniej były pociągające.

Można powiedzieć, jak trafnie zauważa jeden z autorów, że niespójność psychiczna to brak harmonii pomiędzy tym, czego człowiek oczekuje od siebie, kim chciałby być, o czym marzy, a tym, w jaki stanie duchowym, moralnym aktualnie znajduje się. Jest to brak zgodności między ideałami człowieka, które są świadome a potrzebami psychicznymi, które mogą być podświadome. Nie ma ludzi całkowicie spójnych. Istnieje jednak niespójność, która powoduje całkowite rozbicie człowieka. Jest ona często przyczyną niekonsekwencji pomiędzy tym, co człowiek wybrał a tym, czym naprawdę żyje. Niekonsekwencja ta nie jest kwestią kategorii moralnej, lecz psychicznej. Kiedy się mówi o rezygnacji z kapłaństwa lub życia zakonnego, to wymienia się najczęściej następujące argumenty: lęk przed kapłaństwem niepewnym i niejasnym, poczucie samotności i bezużyteczności. Pragnienie małżeństwa jest raczej konsekwencją odejścia niż elementem decydującym o wystąpieniu. Wydaje się, iż te racje mogą być wynikiem napięcia, często nie uświadomionego, które nazywamy niespójnością. Jak wykazują badania, to cztery przypadki na pięć osób porzucających powołanie są połączone z przeżyciem samotności i izolacji. Trudność życia w celibacie objawia 
raczej kryzys osobowości człowieka, kryzys o wiele głębszy, niż problem akceptacji celibatu"3.

Przywołany problem niespójność niestety nie jest czymś z czego się wyrasta. Badania prowadzone przez O. Rullę i jego współpracowników w Instytucie Psychologii w Rzymie pokazały, że około $80 \%$ początkujących kleryków i nowicjuszy zakonnych nie znało głębiej swoich potrzeb psychicznych i wewnętrznych konfliktów. Kłopot w tym, że gdy po kilku latach powtórzono badania na tej samej grupie kontrolnej okazało się, że wyniki niewiele się zmieniły. Może to oznaczać, że dla większości badanych formacja ludzka nie była zbyt owocna ${ }^{4}$. Czy dzisiaj jest podobnie? Sądzę, że jest trochę lepiej, ale obawiam się, że tylko trochę.

Stąd tak ważne jest, by docenić formację ludzką, a w niej nauki antropologiczne, gdyż mogą nam być bardzo pomocne. Chodzi o to, by dojrzale, świadomie i głęboko przeżywać swoje życie. By uniknąć nieustannego kręcenia się wokół siebie, a kapłaństwo mogło być drogą realizacji Bożego powołania, a nie drogą do szukania samego siebie. Mówiąc nieco dosadnie, chodzi o to, by żyć kapłaństwem, a nie z kapłaństwa. Troska o taki styl życia jest z pewnością pragnieniem Boga, ale i ludzką korzyścią. Czy ksiądz, który uwił sobie przysłowiowe „gniazdko”, a kapłaństwo jest dla niego pobożnym zawodem pozwalającym realizować siebie, będzie w nim szczęśliwy? Czy będzie mógł odczuwać radość Ewangelii, która mówi, że „więcej szczęścia jest w dawaniu niż w braniu"(Dz 20,35)?

Dlatego formacja ludzka, którą Jan Paweł II nazwał „fundamentem" jest tak ważna, a w życiu seminaryjnym nie wystarczy zwykłe przystosowanie czy regulaminowa grzeczność (por. PDV 43). Potrzeba zaangażowania i walki, szczerości oraz uczciwości wobec siebie i przełożonych, głębszej refleksyjności, odwagi stawiania mądrych pytań, ale i szukania głębszych odpowiedzi. Materiał do refleksji przynosi nam samo życie, które trzeba umiejętnie czytać i traktować jako uprzywilejowaną drogę poznawania siebie. Jeśli stanie się coś niewłaściwego czy dziwnego, to owszem, szukamy oceny w kluczu norm moralnych, ale ważniejsze od pytania „,co?” jest pytanie „dlaczego?” oraz ,jak?”.

Pamiętam przed laty historię alumna (nie jest klerykiem mojego seminarium), który złamał regulamin i przyniósł do seminarium alkohol, rozpijając później kolegów. Naruszył prawo, ocena moralna tego wydarzenia jest prosta, a kara łatwa do ustalenia. Można było

J.Pierzchalski,Spójnośći niespójność psychiczna. Cyt.za: Chrześcijański portal kierownictwa duchowego Przemiana (http://pierzchalski.ecclesia.org.pl). 
go wyrzucić, napomnieć, oczekiwać przeprosin i zadośćuczynienia. Pewne konsekwencje musiały być wyciągnięte, gdyż sprawa stała się publiczna, ale najciekawsze było pytanie: dlaczego i jak się to stało? Antropologia teologiczna Na początku nie było łatwo znaleźć odpowiedzi na te pytania, musiało upłynąć sporo czasu, potrzebna była pomoc psychologa i praca nad poznawaniem motywów działania. Owocem tego doświadczenia stało się zrozumienie postaw, gdzie sam alkohol nie miał większego znaczenia. Znaczenie miało zaś poczucie osamotnienia, nieumiejętność zaistnienia w grupie, lęk przed oceną innych, obniżone poczucie własnej wartości, kłopot z przeżywaniem autorytetów - trudna relacja z ojcem, nieumiejętność radzenia sobie ze stresem. Problemów było sporo, a żaden z nich nie odnosił się wprost do alkoholu i równie dobrze mógł być rozwiązywany przy pomocy innych używek lub zachowań kompensacyjnych. To banalne, jak na polskie warunki, zdarzenie z alkoholem, może dla kogoś nieznaczące, poddane głębszej refleksji doprowadziło do odkrycia i przepracowania szeregu problemów, których formacja seminaryjna w żaden sposób wcześniej nie podejmowała. Dzięki temu to, co przez moment było dla tego człowieka przekleństwem, stało się początkiem błogosławionej drogi, która pozwoliła mu poznać prawdę o sobie i coś dobrego dla siebie uczynić. Gdyby tej drogi nie podjął, to najprawdopodobniej, niezależnie od stanu życia - czy w kapłaństwie czy w małżeństwie, nosząc w sobie tak liczne problemy emocjonalne, wcześniej czy później, stałby się życiowym rozbitkiem.

\section{Formacja formatorów}

Za własny rozwój w seminarium odpowiedzialny jest każdy sam, a powołanie zawsze ma charakter osobisty. Nikt za mnie nie będzie podejmował decyzji, rozwiązywał problemów czy przeżywał mojego życia. Bóg mnie powołał i to ja muszę dać Mu odpowiedź, a pierwszym moim wychowawcą powinien być Duch Święty. Choć każdy osobiście musi się zaangażować, to jednak nikt nie jest na tej drodze sam. Żyjemy we wspólnocie i powołanie ma kontekst wspólnotowy, otrzymujemy je w Kościele i dla Kościoła. Dlatego Kościół towarzyszy w procesie rozeznawania i realizacji powołania.

Osobami odpowiedzialnymi za właściwe rozeznanie łaski powołania oraz udzielenie adekwatnej pomocy w jej przeżywaniu są głównie, choć nie tylko, wychowawcy seminaryjni. Aby zrealizować to zadanie sami muszą być osobami o dojrzałej i spójnej osobowości, zdolnymi do budowania dobrych relacji oraz posiadający umiejętności pedagogiczne. Ważne, by wykazywali się dobrą znajomością osoby ludzkiej, 
zarówno na poziomie emocjonalnym, intelektualnym, jak i duchowym. Wówczas lepiej będą mogli rozumieć i wspierać rozwój seminarzystów oraz podejmować właściwe decyzje dotyczące ich przyszłości.

Formatorem jednak nikt się nie rodzi, a ukończone studia czy kolejne stopnie naukowe nie są tu wystarczające. Aby stać się wychowawca innych, trzeba wcześniej pozwolić uformować samego siebie. Kto głębiej przepracował własną historię życia, poznał i uporządkował swój wewnętrzny świat oraz nabył osobiste doświadczenie w sztuce rozeznawania duchowego, będzie mógł stawać się przewodnikiem dla innych.

Najbardziej nośnym i twórczym narzędziem formacji jest zawsze osoba samego wychowawcy, gdyż przekaz wartości nie dokonuje się na poziomie strukturalnym (regulaminy, programy, nakazy i zakazy), ale personalnym. Człowiek pracuje nad sobą. Jeśli wychowawca będzie człowiekiem w drodze, który sam się zmaga, rozwija i dojrzewa, jeśli będzie widać w nim owoce życia wiarą i duchową pasję, gdy będzie miał na tyle pokorny, by nie bać się mówić o swoich sukcesach i porażkach, a przy tym będzie potrafił dzielić się życiowym doświadczeniem, nie chowając się za fasadą urzędów, funkcji czy godności kościelnych, wówczas jego przekaz będzie bardzo czytelny. Nawet jeśli nie będzie wiele mówił, to sama jego postawa będzie poruszająca i wychowawcza.

Niezwykle ważna w tym względzie jest odpowiednia polityka personalna na poziomie wyższych przełożonych, którzy w długofalowej perspektywie powinni zadbać o przygotowanie odpowiedniej liczby osób posiadających stosowne kompetencje oraz predyspozycje (osobowościowe i duchowe) do posługi formacyjnej. Obserwacja polskich seminariów pokazuje, że zbyt wiele osób rozpoczynających tam posługę, ma poczucie niekompetencji i jest zaskoczona faktem skierowania ich do pracy formacyjnej. Choć obecnie jest w tej materii znacznie lepiej niż kiedyś, to jednak wiele pozostaje tu jeszcze do zrobienia.

\section{Życie jako droga}

Życie jest wędrówką, a od czasów Abrahama wiara ma strukturę drogi, która czyni z nas pielgrzymów. Wyszliśmy z domu Ojca i do niego zmierzamy. Podobnie rozumowali starożytni wędrowni mnisi, którzy interpretowali życie jako nieustanną pielgrzymkę. Nie traktowali wędrowania jako przejściowego etapu, ale uważali je za podstawowy styl bycia, akcentując jego duchowy sens. Podejmowali zewnętrzną wędrówkę, bo ona pozwalała udać się w drogę wewnętrzną. Przemierzali 
świat nie po to, by zobaczyć coś nowego, ale by poznać i zmienić samych siebie.

Metafora drogi jest dla nas bardzo użyteczna. Obyśmy i my poteologiczna trafili tak przeżywać nasze życie, czytać znaki, jakie spotykamy, być uważnymi i dociekliwymi w szukaniu głębszego rozumienia togo, co się nam wydarza, w stawianiu mądrych pytań. Jeśli będziemy w tym wytrwali i cierpliwi, jeśli nie ulegniemy rutynie oraz nie zgodzimy się na wygodny konformizm, nasze życie będzie ciekawe i twórcze, a przede wszystkim będzie szansą na realizację wspaniałej przygody, do jakiej zaprosił nas Bóg dając kapłańskie powołanie.

Słowa kluczowe: przygotowanie do kapłaństwa, formacja ludzka, dojrzałość ludzka a realizacja powołania, seminarium duchowne.

\section{Bibliografia:}

1. Jan Paweł II, Adhortacja apostolska Pastores dabo vobis o formacji kapłanów we współczesnym świecie, Rzym 1992.

2. Kongregacja ds. Wychowania Katolickiego, Wskazania wychowawcze dla formacji do celibatu kapłańskiego. Rzym 1974.

3. Manenti A., Powołanie. Psychologia i łaska, Kraków 1995, s. 21

4. Pierzchalski J., Spójność i niespójność psychiczna, za: Chrześcijański portal kierownictwa duchowego Przemiana (http://pierzchalski.ecclesia.org.pl). 